\title{
BIOBASED ECONOMY AVAILABLE BIOMASS RESOURCES IN THE CZECH REPUBLIC
}

\author{
Zdenek Wegscheider ${ }^{1}$, Mojmir Sabolovic ${ }^{2}$ \\ Mendel University of Agriculture and Forestry, Czeck Republik

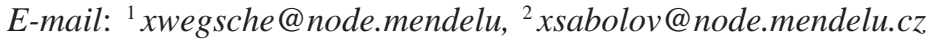 \\ Received 0603 2006; accepted 28042006
}

\begin{abstract}
During the past two decades academia, industry and government have aimed more and more their attention to the phenomenon of a biobased economy providing society with non-food biobased products. Now developing are biomass industries that make an array of commercial products, including fuels, electricity, chemicals, adhesives, lubricants and building materials, as well as new clothing fibers and plastics. Instead of fossil resources "green" biobased economy uses renewable grown or waste biomass. The lead supplying role to the biobased economy is held by a sector of agriculture, above all the crop production. In this manner an effective limitation of food surplus may occur in the EU market and enhance a value added to all vertical industry.

Industrial-scale production of biobased materials in time with consumers' changing attitudes towards sustainable economic and social development may affect a wide array of consequences which nowadays can be tediously estimated. Food safety along with food security is one of the hottest issues especially in the United States, knowing that human population and biobased economy compete in using and processing a broad range of agricultural crops. An energy analysis aspect of this caloric relationship among agricultural sector on the supply side and human population and biobased economy on the other - demand side is assumed to represent the principal aim of this study.

Consequently, there is the need to evaluate whether a quantity of Czech Crop Output Total is possible to nourish the Czech population and whether there is an available caloric surplus suitable as a biomass resource for biobased economy which is actually taking root.
\end{abstract}

Keywords: biobased economy, non-food product, biomass, caloric content, Czech Crop Output Total.

\section{Introduction and objectives}

More than usually academia, industry and government aim their attention to biobased economy providing society with non-food biobased products. Now developing are biomass industries that make an array of commercial products, including fuels, electricity, chemicals, adhesives, lubricants and building materials, as well as new clothing fibers and plastics. Instead of fossil resources "green" biobased economy uses renewable biomass, it means intentionally grown as well as waste biomass. The lead supplying role to the biobased economy is held by an agriculture sector, above all the crop production. Thus, a food surplus effective limitation in the EU crop market may be generated and value added may be enhanced throughout all supply chain.

Industrial-scale production of biobased materials accompanied with consumers' changing attitudes towards sustainable economic and social development may affect a wide array of consequences which nowadays can be tediously estimated. Food safety along with food security is one of the hottest issues especially in the United States, knowing that human population and biobased economics compete each other on the supply side in using and processing a broad range of agricultural crops. An energy analysis aspect of this caloric relationship among agricultural sector on the supply side and human population and biobased economy on the other - demand side is illustrated by Pimentel [1]: "Human societies already use 50 percent of all solar energy assimilated by plants, which utilize less that 1 percent of the solar energy they intercept." With a renewable resourcesbased economy, we risk negative consequences of asking yet more from the Earth.

The aim of this study is to apply energy analysis mentioned above on the situation in the Czech Republic. Energy analysis is a means of quantifying "sustainability," so that "sustainability" is the outcome of a positive or neutral energy balance, rather than only a lofty ideal motivating the search for alternatives to the fossil-energy-based economy of the industrial and post-industrial eras [1]. My objective is to evaluate whether the Czech Crop Output Total is possible to nourish the Czech population and if there is an 
available caloric surplus suitable as a biomass resource for starting biobased economy. We assumed following working procedure:

- Constraints definition,

- calculation of Crop Output Total in calories,

- determination of caloric intake of the Czech population in form of energy expenditure,

- hypothesis confirmation or refutation in working out a caloric self-sufficiency by means of comparing the Crop Output Total in calories and the energy expenditure of the Czech population.

\section{Methodology}

To meet the aim of this study we created a simple energy-based model comparing Crop Output Total in calories and total food needs of the Czech population. Absolute precision is not an objective of these simulations and also the projections of the model are not predictions. This model is mainly supposed to illustrate a caloric capacity of the Czech Crop Output Total. These constraints are assumed:

- Closed economy - foreign exchanges via market system are omitted.

- Animal Output Total, seed production, a hop growing and crop output fed and bedded are ignored.
- Crop Output Total is to satisfy completely the Czech population's food (caloric) needs.

- For the purpose of this exercise, the needs and demands of all people are considered to be equal.

- Crop supply = food production + biobased nonfood production, storing overlapping one year period is not supposed.

- In our basic grain model, we ignore the caloric value added to crops by food industry.

As introduced above, these constraints do simplify reality in a significant manner, indeed. On the other hand, some constraints tend to compensate each other. In advance, closed economy assumption shows true caloric potential of the Czech Crop Output Total.

\section{Crop Output Total of the Czech Republic}

Czech Crop Output Total data shown in Table 1 are based on the Czech Statistical Office report about Gross Agricultural Output in period 2001-2004. Due to estimate appropriately the caloric value of Crop Output Total, we calculated an arithmetic mean of yield quantities for each item to eliminate output fluctuation on final results caused by weather conditions and other factors. As well the aim is not to illustrate structural changes in harvested areas

Table 1. Crop Output Total in the Czech Republic

\begin{tabular}{|c|c|c|c|c|c|c|}
\hline \multirow{2}{*}{ Crop, product } & \multirow{2}{*}{ Unit } & \multicolumn{4}{|c|}{ Volume per year } & \multirow{2}{*}{ Mean } \\
\hline & & 2001 & 2002 & 2003 & 2004 & \\
\hline Wheat & $\mathrm{t}$ & 4476080 & 3866473 & 2637891 & 5042523 & 4005742 \\
\hline Rye & $\mathrm{t}$ & 149298 & 119154 & 159312 & 313348 & 185278 \\
\hline Barley & $\mathrm{t}$ & 1965611 & 1792557 & 2068693 & 2330582 & 2039361 \\
\hline Oat inc. mixtures & $\mathrm{t}$ & 136363 & 167708 & 233560 & 227017 & 191162 \\
\hline Grain maize & $\mathrm{t}$ & 408653 & 616234 & 476371 & 551628 & 513222 \\
\hline Other cereals & $\mathrm{t}$ & 201584 & 208703 & 186569 & 318703 & 228890 \\
\hline Eatable dried pulse & $\mathrm{t}$ & 82766 & 56182 & 53736 & 71962 & 66162 \\
\hline Potatoes & $\mathrm{t}$ & 1130477 & 1105967 & 841465 & 993203 & 1017778 \\
\hline Rape & $\mathrm{t}$ & 973321 & 709533 & 387805 & 934674 & 751333 \\
\hline Poppy & $\mathrm{t}$ & 21294 & 16918 & 19544 & 24821 & 20644 \\
\hline Other oleaginous products & $\mathrm{t}$ & 84135 & 96950 & 193899 & 148990 & 130994 \\
\hline Flax seeds & $\mathrm{t}$ & 1063 & 830 & 810 & 920 & 906 \\
\hline Sugar beet & $\mathrm{t}$ & 3529005 & 3832466 & 3495148 & 3579278 & 3608974 \\
\hline Fruits & $\mathrm{t}$ & 328813 & 429826 & 358728 & 435603 & 388243 \\
\hline Grapes & $\mathrm{t}$ & 68346 & 56682 & 67412 & 69733 & 65543 \\
\hline Vegetables & $\mathrm{t}$ & 421183 & 332294 & 295585 & 322333 & 342849 \\
\hline
\end{tabular}


influenced by agricultural politics and supply and demand blips on the crop markets.

Postulating that energy analysis examines a nourishing capacity of Crop Output Total, we ignore Animal Output Total at all. That is why we ignore also hop, feed crops, bedding products, seeds, spices ${ }^{1}$ and products a priori utilized for biobased economy (medicinal plants, poppy head, flax - retted and sugar beet slabs).

\section{Crop Output Total in calories}

Agricultural sector encompassing crop production and animal production presents an energy transformation process all along with raw material characteristic modifications. However, the main difference between agriculture and other sector consists in greater volume of solar energy being accumulated in the final production [2].

In photosynthesis, solar energy is converted to chemical energy being stored in the form of glucose (sugar). Carbon dioxide, water, and sunlight are used to produce glucose, oxygen, and water. The chemical equation for this process is:

$$
\begin{aligned}
& 2,83 \mathrm{MJ}+6 \mathrm{CO}_{2}+12 \mathrm{H}_{2} \mathrm{O}=> \\
& \mathrm{C}_{6} \mathrm{H}_{12} \mathrm{O}_{6}+6 \mathrm{H}_{2} \mathrm{O}+6 \mathrm{O}_{2} .
\end{aligned}
$$

6 molecules of carbon dioxide $\left(6 \mathrm{CO}_{2}\right)$ and 12 molecules of water $\left(12 \mathrm{H}_{2} \mathrm{O}\right)$ are consumed in this process, while glucose $\left(\mathrm{C}_{6} \mathrm{H}_{12} \mathrm{O}_{6}\right)$, six molecules of oxygen $\left(6 \mathrm{O}_{2}\right)$, and six molecules of water $\left(6 \mathrm{H}_{2} \mathrm{O}\right)$ are produced. Energetic value of plants consists of $98 \%$ of solar energy being accumulated, the rest, $2 \%$ is made up by technologic process in the form of fertilizers, fuels and human labor [2].

Fundamental idea of this article is to answer this simple question: "Is the Czech agricultural sector idealized to the Crop Output Total able to nourish native population, in other words is there a calorific surplus grown available for non-food production purposes?"

To meet conceived aim of this paper we calculated the Czech Crop Output Total in calories, like did analogically Levithan [1] in his paper discussing the nourishing capacity of word rice cultivation sector, in other words the rice diet capacity to feed the world population and at the same time supply the flourishing biobased economy in certain conditions such as soil

\footnotetext{
${ }^{1}$ negligible quantity
}

degradation, GMOs increasing yields per acre, etc. To find out nutrition facts of different commodities, we exploited the well-known U.S. Food and Drug Administration (FDA) caloric database. Nutrition Facts Label (see Fig 1) is very useful for determining the quality of food items, and it is provided in its standard layout for every article in our foods database [3]. The label consists of the following main elements:

Serving size - this element is shown at the top of the label, and most food items can be analyzed for various serving sizes. Nutrients of those items with only one selection of serving size have to be scaled up or down according to the difference of the actual serving size and that used in our database.

Calories and calories from fat - the first value shows the total number of calories stored in that particular serving size of that food item. It should be used for traditional calorie counting purposes, in which dieters strive not to exceed a certain number of calories per day. The second value is mostly used by people on low-fat diets, who limit the consumption of items rich in fat. To calculate a Crop Output Total energy value the first item - calories are handled.

Table 2 shows us different commodities within the Crop Output Total and their energy values related to serving size mentioned in connection with the Nutrition Facts Label (see Fig 1). Energy content is then recalculated to $1 \mathrm{~kg}$ quantity and in particular cases converted using the technology ratio.

During the calculation process of the Czech Crop Output Total in calories, we had met some difficulties which have caused some necessary simplification and idealization of the crop production. In one case, an aggregate item is replaced by particular commodity. In other case, if we can't find out particular energy value, e.g. sugar beet, caloric value of sugar has been utilized and technologic ratio was applied.

The $6^{\text {th }}$ row in Table 2 comprehend an aggregate item "Other cereals" comprising millet, Indian millet, buckwheat and other marginally grown cereals. In fact, the most important commodities are millet and buckwheat, as typical, we've chosen a caloric value of millet, which this way is to represent all aggregated item. "Other cereals" may be used for food and feed purposes; "Summary Bulletin on Cereals" [2004: 86] reported that food and non-food utilization of "other cereals" are equal amounting $50 \%$. That is why we applied to energy calculation of this item the recalculating ratio equal to 0.5 .

The $7^{\text {th }}$ table item "Eatable dried pulse" comprises garden pea, haricot, and other marginal pulses grown 
Table 2. Commodity energy value $[4,5]$

\begin{tabular}{|c|c|c|c|c|c|c|}
\hline Crop, product ${ }^{2}$ & Specification $^{3}$ & T. $\mathbf{r}^{4}$ & $\begin{array}{l}\text { Quantity } \\
\text { (g) }\end{array}$ & $\begin{array}{c}\text { Energy } \\
\text { (kcal/quantity) }\end{array}$ & $\begin{array}{c}\text { Energy } \\
\text { (kcal/1 } \\
\text { kg) }\end{array}$ & $\begin{array}{c}\text { Energy when } \\
\text { ratios used } \\
\text { (kcal/1 kg) }\end{array}$ \\
\hline Wheat & Wheat, Durum & $\mathrm{x}$ & 192 & 651 & 3390,63 & $\mathrm{x}$ \\
\hline Rye & Rye & $\mathrm{x}$ & 169 & 566 & 3349,11 & $\mathrm{x}$ \\
\hline Barley & Barley & $\mathrm{x}$ & 184 & 651 & 3538,04 & $\mathrm{x}$ \\
\hline Oat inc. mixtures & Oats & $\mathrm{x}$ & 156 & 607 & 3891,03 & $\mathrm{x}$ \\
\hline Grain maize & Corn, Yellow & $\mathrm{x}$ & 166 & 606 & 3650,60 & $\mathrm{x}$ \\
\hline Other cereals & Millet & 0,500 & 200 & 756 & 3780,00 & 1890,00 \\
\hline Eatable dried pulse & Peas, Green & $\mathrm{x}$ & 145 & 117 & 806,90 & $\mathrm{x}$ \\
\hline Potatoes & $\begin{array}{l}\text { Potato, Flesh } \\
\text { and Skin }\end{array}$ & $\mathrm{x}$ & 369 & 284 & 769,65 & $\mathrm{x}$ \\
\hline Rape & Canola Oil & 0,450 & 100 & 884 & 8840,00 & 3978,00 \\
\hline Poppy & Poppy Seeds & $\mathrm{x}$ & 9 & 47 & 5222,22 & $\mathrm{x}$ \\
\hline $\begin{array}{l}\text { Other oleaginous } \\
\text { pr. }\end{array}$ & Sunflower Seeds & $\mathrm{x}$ & 46 & 262 & 5695,65 & $\mathrm{x}$ \\
\hline Flax seeds & Flaxseed & $\mathrm{x}$ & 155 & 763 & 4922,58 & $\mathrm{x}$ \\
\hline Sugar beet & Sugar & 0,152 & 200 & 774 & 3870,00 & 588,24 \\
\hline Fruits & Apples & $\mathrm{x}$ & 125 & 65 & 520,00 & $\mathrm{x}$ \\
\hline Grapes & Grapes & $\mathrm{x}$ & 92 & 62 & 673,91 & $\mathrm{x}$ \\
\hline Vegetables & $\begin{array}{l}\text { Cabbage + } \\
\text { Carrots }+ \\
\text { Onions }\end{array}$ & $\mathrm{x}$ & 1000 & 262,94 & 262,94 & $\mathrm{x}$ \\
\hline
\end{tabular}

2 according to the Czech Statistical Office

${ }^{3}$ according to "Nutrition Facts Labels"

${ }^{4}$ recalculating or technologic ratio

\begin{tabular}{|c|c|}
\hline \multicolumn{2}{|l|}{ Serving Size 1 cup (192.0g) } \\
\hline \multicolumn{2}{|l|}{ Amount Per Serving } \\
\hline \multirow{2}{*}{ Calories 651} & Calories from Fat 43 \\
\hline & \% Daily Value \\
\hline Total Fat $4.7 \mathrm{~g}$ & $7 \%$ \\
\hline Saturated Fat $0.9 \mathrm{~g}$ & $4 \%$ \\
\hline \multicolumn{2}{|l|}{ Polyunsaturated Fat $1.9 \mathrm{~g}$} \\
\hline \multicolumn{2}{|l|}{ Monounsaturated Fat $0.7 \mathrm{~g}$} \\
\hline \multicolumn{2}{|l|}{ Cholesterol Omg } \\
\hline \multicolumn{2}{|l|}{ Sodium 4mg } \\
\hline \multicolumn{2}{|l|}{ Total Carbohydrates $136.6 \mathrm{~g}$} \\
\hline \multicolumn{2}{|l|}{ Protein $26.3 \mathrm{~g}$} \\
\hline \multicolumn{2}{|l|}{ Vitarnin A. $0 \%$} \\
\hline \multicolumn{2}{|c|}{$\begin{array}{lll}\text { Calcium } 7 \% & \text { Iron } 38 \%\end{array}$} \\
\hline \multicolumn{2}{|l|}{ Nutritional Units 13} \\
\hline \multicolumn{2}{|l|}{ Eased on a 2000 calorie diet } \\
\hline
\end{tabular}

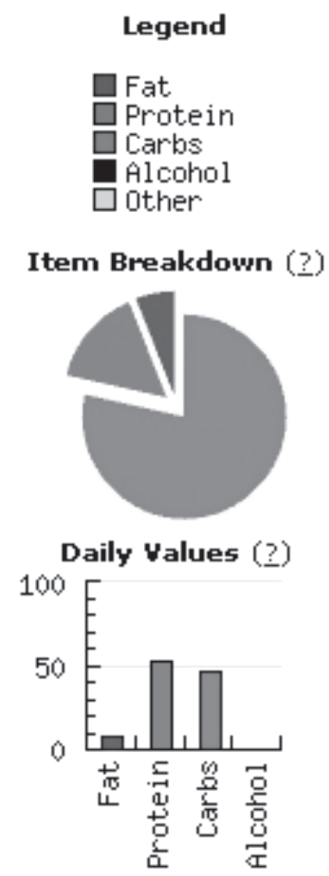

Fig 1. Calories in wheat, durum $[6,7]$ 
in smaller quantities. "Summary Bulletin on Pulses" (2004: 13) published by Ministry of Agriculture states that approximately $76 \%$ of yielding area is devoted to peas, so we've simplified an energy value of "Eatable dried pulse" by using that of peas.

For those simplifying purposes the $11^{\text {th }}$ item "Other oleaginous products" energy value is represented by that of sun-flower, although it encompasses white mustard, soybean and flax.

However we couldn't find nutrition facts as well as caloric values of sugar beet and rape seeds. That is why the caloric values mentioned previously are calculated out of the caloric content of final products that means sugar and rape seed oil. Further, this final product's energy content is modified using relevant technologic ratio taking into account an effective proportion of final product at the particular crop.

Throughout the 2003/2004 sugar beet campaign the sugar content has been taken - satisfactorily amounting to $15.2 \%$ (Summary Bulletin on Sugar beet, 2004: 31). Whereas rape seed oil content $39.8-45 \%$ has been referred $^{5}[8]$ depending on the seed specimen and variety. During further calculations $45 \%$ oil content is assumed knowing that other by-products used in stock feeding are omitted.

The $14^{\text {th }}$ table item, caloric content of "Fruits", is simplified using the energy value of apples. In fact apples do represent $70 \%$ of fruits harvested in the Czech Republic (Summary Bulletin on Fruits, 2004: 29).

The last row in Table 2 is occupied by "Vegetables". According to Summary Bulletin on Vegetables (2004:13), $58 \%$ of this commodity harvested throughout 2004 represents yield of cabbage (red and white), carrot and onion. Thus we assume a weighted arithmetic mean of calorific value concerning these commodities as representative for the whole item "Vegetables" (consult Table 3).
As mentioned in "Methodology" chapter, the calculation of Crop Output Total in calories is rather simplified and does not correspond completely with the Gross Agricultural Output. Within our basic grain model we postulate in particular:

- Animal Output Total, seed production, a hop growing and crop output fed and bedded are ignored.

- Crop Output Total is to satisfy completely the Czech population food (caloric) needs.

- In our basic grain model, we ignore the caloric value added to crops by food-processing industry.

Finally, when all caloric value of crop volume calculated, we can sum and the Crop Output Total in calories amounting to $3,161 \mathrm{E}+16 \mathrm{kcal}$ does result (Table 4).

\section{Caloric consumption of Czech populations}

Caloric consumption of the Czech population is assumed to correspond with total energetic expenditure of all that population. It comes out from a simple idea: A demanded figure results from the number of population multiplied with energetic expenditure expected. Naturally, the Czech population is statistically classified, i.e. placed into groups based on their age.

In the context of human energy requirements area $\mathrm{FAO}^{6}$ distinguish [5]:

- Energy requirement - the amount of food energy needed to balance energy expenditure in order to maintain body size, body composition and a level of necessary and desirable physical activity consistent with long-term good health.

- BMR (Basic Metabolic Rate) - the amount of energy used for basal metabolism in a period of time ${ }^{7}[9,10]$.

Table 3. Caloric value - item "Vegetables"

\begin{tabular}{|c|c|c|c|c|c|}
\hline $\begin{array}{c}\text { Commodity } \\
\text { specification }\end{array}$ & Weight & Quantity (g) & $\begin{array}{c}\text { Energy } \\
\text { (kcal/quantity) }\end{array}$ & $\begin{array}{c}\text { Energy } \\
\text { (kcal/1 kg) }\end{array}$ & Mean \\
\hline Cabbage & 0,52 & 75 & 9 & 120,00 & \multirow{2}{*}{262,94} \\
\cline { 1 - 4 } Carrots & 0,22 & 72 & 30 & 416,67 & \\
\hline Onions & 0,26 & 160 & 67 & 418,75 & \\
\hline
\end{tabular}

\footnotetext{
${ }^{5}$ the least oily variety Spacer (MSP 04) 39,8 \% ... up to yielding variety Catonic 45,0\%

${ }^{6}$ Food and Agriculture Organization of the United Nations

${ }^{7} \mathrm{BMR}$ is measured under standard conditions that include being awake in the supine position after ten to 12 hours of fasting and eight hours of physical rest, and being in a state of mental relaxation in an ambient environmental temperature that does not elicit heat-generating or heat-dissipating processes.
} 
Table 4. Crop Output Total in calories

\begin{tabular}{|l|r|r|r|}
\hline \multicolumn{1}{|c|}{ Commodity specification } & Caloric value (kcal/kg) & \multicolumn{1}{c|}{ Volume (t) } & $\begin{array}{c}\text { Caloric value of volume } \\
\text { harvested (kcal) }\end{array}$ \\
\hline Wheat, Durum & 3390,625 & 4005742 & $1,358 \mathrm{E}+13$ \\
\hline Rye & 3349,112 & 185278 & $6,205 \mathrm{E}+11$ \\
\hline Barley & 3538,043 & 2039361 & $7,215 \mathrm{E}+12$ \\
\hline Oats & 3891,026 & 191162 & $7,438 \mathrm{E}+11$ \\
\hline Corn, Yellow & 3650,602 & 513222 & $1,874 \mathrm{E}+12$ \\
\hline Millet & 1890,000 & 228890 & $4,326 \mathrm{E}+11$ \\
\hline Peas, Green & 806,897 & 66162 & $5,339 \mathrm{E}+10$ \\
\hline Potato, Flesh And Skin & 769,648 & 1017778 & $7,833 \mathrm{E}+11$ \\
\hline Canola oil & 3978,000 & 751333 & $2,989 \mathrm{E}+12$ \\
\hline Poppy Seeds & 5222,222 & 20644 & $1,078 \mathrm{E}+11$ \\
\hline Sunflower Seeds & 5695,652 & 130994 & $7,461 \mathrm{E}+11$ \\
\hline Flaxseed & 4922,581 & 906 & $4,459 \mathrm{E}+09$ \\
\hline Sugar & 588,240 & 3608974 & $2,123 \mathrm{E}+12$ \\
\hline Apples & 520,000 & 388243 & $2,019 \mathrm{E}+11$ \\
\hline Grapes & 673,913 & 65543 & $4,417 \mathrm{E}+10$ \\
\hline Cabbage + Carrots + Onions & 262,940 & 342849 & $9,015 \mathrm{E}+10$ \\
\hline Sum & & $x$ & $x, 161 \mathrm{E}+13$ \\
\hline
\end{tabular}

- PAL (Physical Activity Level) - physical activity level.

- TEE (Total energy expenditure) - the energy spent, on average, in a 24-hour period by an individual or a group of individuals. By definition, it reflects the average amount of energy spent in a typical day, but it is not the exact amount of energy spent each and every day. TEE for 24 hours expressed as a multiple of BMR, and calculated as TEE/BMR for 24 hours. In adult men and non-pregnant, nonlactating women, BMR times PAL is equal to TEE or the daily energy requirement.

Czech Statistical Office classifies the Czech population into groups based on age as follows: 0-14 years, 1564 years, over 65 years; for men as well as for women.

Since FAO uses slightly different and more complex

Table 5. Age classification of the Czech population encompassing a level activity assignment

\begin{tabular}{|c|c|c|c|}
\hline TEE & Age classes CZSO & Age classes FAO & PAL \\
\hline \multirow{2}{*}{$\begin{array}{c}\text { TEE }=\text { population in } \\
\text { particular class } x \text { BMR } x\end{array}$} & $0-14$ years & $7-8$ years & 1,60 \\
\cline { 2 - 4 } PAL & $15-64$ years & $30-59$ years & 1,75 \\
\cline { 2 - 4 } & $65+$ years & $60+$ years & 1,75 \\
\hline
\end{tabular}

Table 6. Total Energy Expenditure of the Czech population per year

\begin{tabular}{|c|c|c|c|c|c|c|c|}
\hline \multirow{2}{*}{ Age } & \multicolumn{2}{|c|}{ Situation 31.12.2004 } & \multirow{2}{*}{ Age } & \multicolumn{2}{|c|}{ Total Energy Expenditure per day (kcal) } & TEE p. year \\
\cline { 2 - 5 } & Men & Women & & Men & Women & Population & (kcal) \\
\hline $0-14$ & 784186 & 742760 & $7-8$ & 1700 & 1550 & 2484394200 & $9,06804 \mathrm{E}+11$ \\
\hline $15-64$ & 3638782 & 3620219 & $30-59$ & 3150 & 2400 & 20150688900 & $7,355 \mathrm{E}+12$ \\
\hline $65+$ & 557945 & 876685 & +60 & 2660 & 2200 & 3412840700 & $1,24569 \mathrm{E}+12$ \\
\hline Sum & 4980913 & 5239664 & $x$ & $x$ & $x$ & 26047923800 & $9,50749 \mathrm{E}+12$ \\
\hline
\end{tabular}




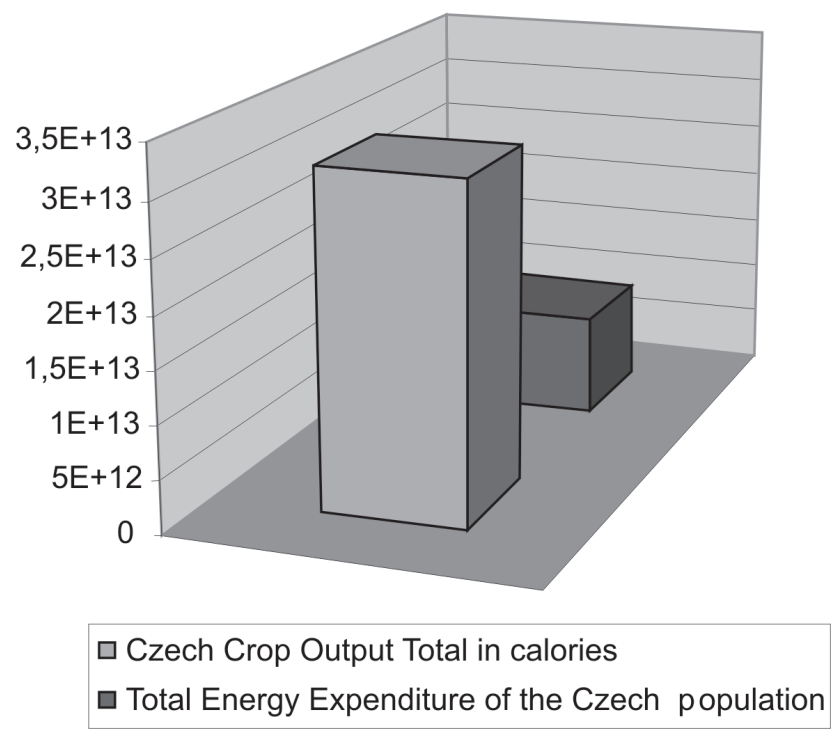

Fig 2. Comparison of the Crop Output Total and the Total Energy Expenditure

age classes, we realized a simplified assignment (shown in Table 5); e.g. the group of children aged to 14 years is assumed to meet energetic expenditure of 7 to 8 years aged kids from FAO statistics [11].

The Physical Activity Level determining Total Energy Expenditure was set up 1.75 for adults 1.6 for children up to 15 years which means lower level of active lifestyle. Further, TEE is influenced by weight of each person. So we picked up typical men weighting 80 kilos and typical women weighting 65 kilos (Table 6, Fig 2).

\section{Conclusions}

Within the one-year period, the Czech Crop Output Total calculations in calories as well as the evaluation of Czech population Total Energy Expenditure of has unambiguously proven a caloric self-sufficiency of the Czech Republic despite certain basic grain model constraints which have been set up to make a computation process easier. Closed economy assumption seems to be rather insignificant if we are to examine a nourishing potential of the Czech agriculture taking into account only the Czech Crop Output Total. Thus, a caloric surplus occurred may be identified as a resource for the biobased economy.

On the other hand, animal Output Total ignored may affect a result significantly knowing that e.g. 2/3 of wheat grown within the Czech Crop Output Total is transformed by feed industry. The aim of this paper is to analyze a caloric self-sufficiency of the Czech Republic meeting "ceteris paribus" conditions in finding out an energy surplus comparing the Crop
Output Total and Total Energy Expenditure of the whole population. Thus, the animal output total may be omitted.

As you can see in the Figure 1, a comparison of the Crop Output Total and the Total Energy Expenditure of the whole population generates a caloric surplus available to the biobased industry.

Therefore, the caloric surplus of the Czech Crop Output Total may be formulated in the following equation and may be expected to provide the biobased economy:

Czech Crop Output Total in calories -Total Energy Expenditure of the Czech population =

$3.161 \mathrm{E}+13(\mathrm{kcal})-9.50749 \mathrm{E}+12(\mathrm{kcal})=$ $2.2092 \mathrm{E}+13(\mathrm{kcal})=22.092$ peta calories .

Relatively compared we can find out the Czech Crop Output Total in calories exceeding 3.32 times the Total Energy Expenditure of the Czech population.

\section{References}

1. Levitan, L. How Many Ways Can We Skin this Cat Called Earth? Risks and Constraints to the Biobased Economy. In The Biobased Economy of the Twenty-First Century: Agriculture Expanding into Health, Energy, Chemicals, and Materials. Ithaca: National Agricultural Biotechnology Council, 2000, s. 139-154.

2. Váňa, J. Skripta z předmětu ekologie a ekotechnika [online]. Prague: Published 1993, updated 1998 [cit. 200509-15]. Available from: http://stary.biom.cz/clen/jv/ obsah.html

3. JEVIČ, Petr - Šedivá, Zdeňka. Využití zemědělské 
produkce k nepotravinářským účelům [online]. Prague: Published in 2004 [cit. 2005-08-26]. Available from: http:/ /www.vuzt.cz/vyzkum/2004/jevic1.htm.

4. Český statistický úrad : Věkové složeni obyvatel České republiky podle pohlaví a věkových skupin v roce 2004 [online]. Prague: Published 23.05.2005 [cit. 2005-07-07]. Available from: http://www.czso.cz/csu/edicniplan.nsf/ t/060041792D/\$File/40030501.pdf

5. Český statistický úr̆ad. Hrubá zemědělská produkce v ČR za rok 2004 (ve stálých cenách r. 1989) [online]. Prague: Published 12.05.2005 [cit. 2005-07-07]. Available from: http://www.czso.cz/csu/edicniplan.nsf/t/ FF0023F920/\$File/2101rr01.xls

6. FAO. Food and Nutrition Technical Report Series: Human Energy Requirements, Report of a Joint FAO/ WHO/UNU Expert Consultation [online]. Rome: [cit. 2005-07-08]. Available from: ftp://ftp.fao.org/docrep/fao/ 007/y5686e/y5686e00.pdf

7. Ministerstvo zemědělství České Republiky. Situačnía výhledová zpráva obiloviny [online]. Prague: Published in september 2004 [cit. 2005-08-17]. Available from: http://www.mze.cz/attachments/SVZ_obili_9_2004.pdf

8. Ministerstvo zemědělství České Republiky. Situační $a$ výhledová zpráva zelenina [online]. Prague: Published in december 2004 [cit. 2005-08-17]. Available from: http://www.mze.cz/attachments/svz_zel_12_04.pdf

9. Ministerstvo zemědělství České Republiky. Situační a výhledová zpráva luskoviny [online]. Prague: Published in december 2004 [cit. 2005-08-17]. Available from: http://www.mze.cz/attachments/LUSKOVINY12_04.pdf

10. Ministerstvo zemědělství České Republiky. Situační $a$ výhledová zpráva ovoce [online]. Prague: Published in september 2004 [cit. 2005-08-17]. Available from: http:/ /www.mze.cz/attachments/SVZ_ovoce_9_04.pdf

11. Ministerstvo zemědělství České Republiky. Situační $a$ výhledová zpráva cukrovka - cukr [online]. Prague: Published in december 2004 [cit. 2005-08-26]. Available from: http://www.mze.cz/attachments/cukr12_04.pdf 